\title{
How size of cattle influences grazing behaviour
}

\author{
R Ferrer, M Petit, P D'hour, G Béchet \\ INRA, LAHM, Theix , 63122 St-Gènes-Champanelle, France
}

Intake is determined by size and physiological state of animals. In grazing conditions, Allden and Whittaker (1970, Aust J Agric Res 21, 755766) defined herbage intake $(\mathrm{HI})$ in terms of the components of ingestive behaviour : bite weight (BW), biting rate (BR) and grazing time (GT) : HI = BW $\times$ BR $\times$ GT. The aim of this study was to assess how size of cattle, which was fixed by age, influences grazing behaviour.

Two animal groups, balanced in weight, were chosen from a Charolais herd. Each group comprised 3 types of females : four mature dry cows, four 18-month-old heifers and four 8-month-old weaned calves. A factorial design with 2 sward heights and 2 periods was used. Animal groups were allocated to different sward heights according to period. Cattle were strip-grazed (a fresh area of herbage each day) on leafy regrowths of cocksfoot differing in age (2 or 8 weeks), corresponding to sward heights (15 to $51 \mathrm{~cm}$ ) which have been considered as unrestricting intake.

Herbage intake were estimated individually by period (over 7 days) using the n-alkane method (Mayes et al, 1986, J Agric Sci, Camb, $107,161-170)$, and grazing behaviour was visually recorded throughout 2 days (from dawn to dusk) during each period. Grazing time was recorded at 5 -min intervals ('scan data') and biting rate by counting the number of bites taken during $2 \mathrm{~min}$
(8-10 records/animal/day). Bite weight was estimated daily from the ratio $\mathrm{Hl} /(\mathrm{GT} \times \mathrm{BR})$.

As expected (Hodgson, 1985, Proc Nutr Soc $44,339-346)$, herbage intake and grazing behaviour were always influenced by sward height $(P<0.001)$, but interactions between sward height and animal class were not significant. Herbage intake per $\mathrm{kg}$ live weight was significantly lower for cows than for calves and heifers, the latter being the highest. Bite weight was well related to live weight as Penning et al, (1991, Appl Anim Behav, 31, 237-250) found for sheep, although Gordon and Illius (1988, Funct Ecol, 2, 15-22) are not in agreement in their study between species. Grazing time decreased and biting rate increased with live weight. However, intake rate per $\mathrm{kg}$ live weight was lower for calves than for older cattle.

In conclusion, to supply the relatively higher nutritional requirements of growing cattle, the major mechanism of compensation employed by cattle is grazing time. Moreover, 18-monthold heifers, which are more experienced grazers than weaned calves, are able to reach higher intake rates per $\mathrm{kg}$ live weight, because of their biting rate which is quite similar to that of cows. Bite weight, as herbage intake, is almost isometric to live weight in such unrestricted sward conditions.

$\begin{array}{lccccc}\text { Animal type } & \text { Cow } & \text { Heifer } & \text { Calf } & \text { sed }^{*} & \text { Size effect } \\ \text { Live weight }(\mathrm{kg}) & 702 & 433 & 272 & & \\ \text { Intake }(\mathrm{kg} \mathrm{OM} / \mathrm{LW}) & 15.2 & 19.1 & 17.0 & 0.50 & \mathrm{P}<0.001 \\ \text { Intake rate } & & & & & \\ \text { (mg OM/min } / \mathrm{kg} \mathrm{LW}) & 42.4 & 44.2 & 37.5 & 1.64 & \mathrm{P}<0.05 \\ \text { Bite weight (mg OM/kg LW) } & 1.03 & 1.09 & 1.15 & 0.070 & \mathrm{NS} \\ \text { Grazing time (min) } & 367 & 437 & 461 & 12 & \mathrm{P}<0.001 \\ \text { Biting rate (bites/min) } & 46 & 46 & 41 & 0.9 & \mathrm{P}<0.001\end{array}$

* sed : standard error of difference.

The authors should like to thank Mrs $\mathrm{J}$ Atzeni for technical assistance. 